\title{
THE ESTIMATION OF PROTEIN IN CEREBROSPINAL FLUID USING THE M.R.C. PHOTOMETER
}

BY

\author{
W. B. YEOMAN \\ From the Department of Pathology, Frenchay Hospital, Bristol
}

(RECEIVED FOR PUBLICATION AUGUST 20, 1954)

Turbidometric methods are widely emp!oyed for the estimation of protein in cerebrospinal fluid (C.S.F.). Precipitation is generally effected using salicylsulphonic acid, and subsequent comparison made with standard reference tubes, e.g., of the formazin gelatin type (King, 1951a). Unfortunately these suffer "ageing," and matching in artificial light is often difficult.

The following technique has been employed in this laboratory for the past two years.

\section{Method}

To $1 \mathrm{ml}$. of C.S.F. in a 6 in. by $\frac{5}{5}$ in. test-tube is added $3 \mathrm{ml}$. of $3 \%$ aq. salicylsulphonic acid solution. mixed, and allowed to stand for five minutes. At the end of this time the turbid suspension is introduced into the right-hand cell of the photometer, using a distilled water blank in the other cell. Matching is a; for a haemoglobin estimation (No. 2 eyepiece, Ilford yellow/green filter 625), and correction is for personal reading error using the standard wedge. The corrected reading is a direct measure of the concentration of protein in $\mathrm{mg}$. per $100 \mathrm{ml}$. of fluid.

To test the efficiency of the method, 350 clear fluids were assayed for protein content by $(a)$ direct comparison with standard tubes. $(b)$ the photometric method described, $(c)$ the micro-Kjeldahl method using $\mathrm{SeO}_{2}$ (King. 1951b), and $(d)$ the micro-Kjeldahl $\stackrel{\infty}{\omega}$ method followed by iodometric titration (Rappaport is and Lasowski, 1943).

Comparison of the results of method $(a)$ with $(c)$ 음 and $(d)$ showed a mean standard deviation for the series of $\pm 5.2 \mathrm{mg}$., and for method $(b)$ with $(c)$ and (d) a mean standard deviation of $\pm 1.8 \mathrm{mg}$.

Further, comparison of methods $(a)$ and $(b)$ in $\frac{\text { c }}{c}$ a series of 2.500 specimens has confirmed that the photometric method always yields results of the same $\vec{e}$ order, but reveals that the photometric method or affords greater facility for detecting small changes. in protein concentration in the C.S.F. when patientso are being subjected to daily lumbar puncture.

\section{Conclusion}

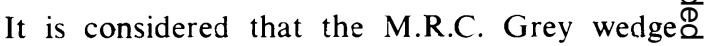
photometer is an adequate instrument for esti- $\overrightarrow{\vec{O}}$ mating protein content of C.S.F.

It can also be used for those other turbidometric procedures which normally require comparison: with standard protein reference tubes, e.g., the thymol turbidity test and the zinc sulphate test.

\section{REFERENCES}

King, E. J. (1951a). Micro-analysis in Medical Biochemistry, 2nd ed., p. 97. Churchill, London.

Rappaport. F., and Lasowski. E. (1943). J. Lab. clin. Med., 28, 1640.0 